\title{
Menggali Intervensi Solutif dan Alternatif Kebijakan terhadap Problem Demografi Lokal
}

\author{
Amir Dedoe ${ }^{1 *}$ \\ ${ }^{1}$ Jurusan Sosiologi, Universitas Bangka Belitung, 33172, Bangka, Indonesia
}

Info Artikel

Dikirim: Apr 20, 2020

Diterima: Jun 25, 2020

Dipublikasi: Jul 30, 2020

Kata Kunci:

Dampak Sosial;

Kebijakan Solutif;

Nikah Dini;

Perceraian.

Koresponden:

Amir Dedoe,

Jurusan Sosiologi

Universitas Bangka Belitung

Email:

Editor@jpi.ubb.ac.id

Cantuman Sitasi:

Dedoe, Amir. 2020. Menggali

Intervensi Solutif dan

Alternatif Kebijakan terhadap

Problem Demografi Lokal.

Journal of Political Issues.

2(1); $\quad$ 47-57. Doi:

https://doi.org/10.33019/jpi.v

$2 \mathrm{i} 1.20$

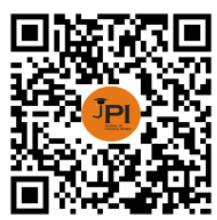

DOI:

https://doi.org/10.33019/jpi.v $2 \mathrm{i} 1.20$

Lisensi:

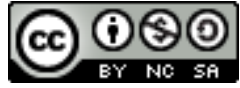

Attribution-NonCommercial-

ShareAlike 4.0 International

(CC- BY-NC-SA 4.0)

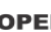

ACCESS

\begin{abstract}
ABSTRAK
$\overline{\text { Abstract This article intends to conduct a critical study as well as to elaborate empirically }}$ related issues and social impacts of early marriage and divorce trends in the Bangka Belitung Islands Province. This study departs from empirical facts that show the high trends of early marriage and divorce that are closely interrelated in recent years. The method used is the study of literature, as well as a review of documents related to relevant studies concerning the impact and problems of early marriage and divorce. This study found that several factors that triggered early marriage and divorce were the local economic landscape which in the last few years was so dependent on the tin extractive industry, and also the problem of post-mining economic transition which also triggered the high trends of early marriage and divorce in Bangka Belitung. Both of these paradoxes have a very strong relationship so that it correlates with the impact and social vulnerability faced by early marriage couples, and also who decide divorce. This condition in turn also affects the capacity, quality, and harmonization of early and divorced marriage couples. Furthermore, other conditions of vulnerability faced by those who engage in early marriage and decide to divorce, even though they are casuistic in nature, often also experience domestic violence, as well as the economic fate of relatively weak and unstable families.
\end{abstract}

Abstrak Artikel ini bermaksud untuk melakukan telaah kritis sekaligus untuk mengelaborasi secara empirik terkait persoalan dan dampak sosial nikah dini dan tren perceraian di Provinsi Kepulauan Bangka Belitung. Kajian ini berangkat dari fakta empiris yang menunjukkan tingginya tren pernikahan dini serta perceraian yang saling berkaitan erat dalam beberapa tahun terakhir. Metode yang digunakan yaitu dengan studi literatur, serta telaah dokumen terkait studi yang relevan menyoal dampak dan problematika nikah dini dan perceraian. Studi ini menemukan bahwa beberapa faktor penyebab yang memicu terjadinya nikah dini dan perceraian yaitu lanskap ekonomi lokal yang dalam beberapa tahun terakhir begitu bergantung pada industri ektraktif timah, dan juga persoalan transisi ekonomi pasca tambang yang juga memicu tingginya tren pernikahan dini dan perceraian di Bangka Belitung. Kedua paradoks tersebut memiliki keterkaitan yang sangat kuat sehingga berkorelasi terhadap dampak dan kerentanan sosial yang dihadapi oleh pasangan nikah dini, dan juga yang memutuskan cerai. Kondisi tersebut pada giliranya juga mempengaruhi kapasitas, kualitas, serta harmonisasi pasangan nikah dini dan cerai. Lebih lanjut, kondisi kerentanan lain yang justru dihadapi oleh mereka yang melakukan nikah dini dan memutuskan bercerai, walaupun bersifat kasuistik, justru juga kerapkali mengalami kekerasan dalam rumah tangga, serta nasib ekonomi keluarga yang relatif lemah dan tidak stabil.

\section{Tentang Penulis:}

Amir Dedoe, M.Si, menyelesaikan studi Magister (S2) Sosiologi pada Universitas Hasanuddin Makassar pada tahun 2010 dan saat ini sedang menempuh pendidikan doktoral (S3) Jurusan Sosiologi Universitas Negeri Makassar. Penulis adalah Dosen Sosiologi Universitas Bangka Belitung. 


\section{PENDAHULUAN}

Indonesia Emas 2045 adalah sebuah visi dimana Indonesia akan mencapai kondisi negara yang maju, makmur, modern, madani, dan dihuni oleh masyarakat yang berperadaban dan berkemajuan. Salah satu upaya untuk mewujudkan Visi Indonesia Emas 2045 adalah melalui penguatan kualitas pembangunan manusia Indonesia yang holistik, setara, humanis, berkeadilan gender, dan pembangunan anak-anak Indonesia yang terjamin hak-haknya. Tentu, dalam hal ini, konteks keluarga menjadi salah satu institusi krusial sekaligus strategis, yang menjadi kunci penting dalam suksesi pembangunan sebuah negara bangsa (Idrus \& Ferdian, 2019).

Dalam kalimat yang berbeda, dengan membangun keluarga yang berkualitas, diyakini akan mampu berkontribusi nyata dalam mengkongkretkan cita-cita bangsa yang maju, makmur, modern, madani, dan beradab sesuai dengan Visi Indonesia Emas 2045. Tentu harus ada desain demografi yang lebih terukur, khususnya di bidang tata kelola dan harmonisasi hubungan di dalam lingkungan keluarga. Tujuannya tentu dalam rangka untuk memastikan lanskap kehidupan generasi mudanya lebih berkualitas secara berkelanjutan. Bagaimanapun juga, kondisi ini akan mempengaruhi kualitas dan produktivitas dari berbagai aspek sosialekonomi dan politik suatu daerah bahkan negara. Inilah aspek penting demografi yang mesti menjadi atensi semua stakeholders. Adapun salah satu aspek yang perlu menjadi perhatian untuk membangun keluarga berkualitas adalah usia pasangan yang akan menikah dan membangun sebuah keluarga tersebut. Di Indonesia sendiri, berdasarkan UU No. 16 Tahun 2019 tentang Perkawinan, pasangan yang ingin menikah, minimal harus berusia 19 Tahun.

Dengan merujuk pada peraturan tersebut, jika ada pasangan yang menikah di bawah usia 19 tahun, maka sudah pasti termasuk ke dalam kategori pernikahan anak. Namun demikian, UU itu pun seolah masih memberi kelonggaran soal usia pernikahan, sebab masih memuat aturan yang berbunyi, "jika ada pasangan yang ingin menikah sebelum mencapai usia 19 Tahun, masih memungkinkan untuk dilangsungkan dengan syarat orang tua pasangan yang bersangkutan meminta dispensasi kepada pengadilan dengan alasan sangat mendesak disertai bukti-bukti yang cukup (bunyi Ayat 2 dalam UU No. 16 Tahun 2019)". Sebagai catatan, dalam hukum international, yang namanya pernikahan anak sudah ditetapkan sebagai salah satu bentuk kekerasan terhadap anak dan merupakan pelanggaran terhadap hak asasi manusia (Kementerian Pemberdayaan Perempuan dan Perlindungan Anak Republik Indonesia, 2016).

Hadirnya regulasi yang mengatur sedemikian rupa soal usia pernikahan, sebagaimana yang sudah disinggung sebelumnya itu, menurut pelbagai sumber, adalah untuk menyelamatkan anak dari praktik pernikahan di bawah umur (pernikahan anak) (Hidayat, 2019). Indonesia sendiri saat ini, dalam hal pernikahan anak, menduduki peringkat kedua tertinggi di ASEAN (Nusantara, 2020; Rahmawati, 2020). Berkaitan dengan persoalan ini, Menteri Pemberdayaan Perempuan dan Perlindungan Anak (PPPA), Prof. Yohana Susana Yembise mengatakan bahwa, rumusan UU No. 16 Tahun 2019 sebagai revisi dari UU No. 1 Tahun 1974 adalah salah satu bentuk upaya untuk menekan angka pernikahan anak di Indonesia yang saat ini sangat tinggi, juga sebagai langkah untuk melindung anak Indonesia demi mewujudkan usia emas bagi anak-anak tanpa ada kekerasan terhadap mereka (Hidayat, 2019).

Jika merujuk dari Measure DHS, ICF Macro Tahun 2011 (BKKBN, 2012) tercatat bahwa jumlah perempuan muda di Indonesia dengan usia 10-14 tahun menikah sebanyak 0.2 $\%$ atau lebih dari 22.000 wanita atau usia muda sudah melakukan pernikahan dini. Jumlah dari perempuan muda berusia 15-19 tahun yang menikah lebih besar jika dibandingkan dengan lak-laki muda berusia tersebut.

Dari seluruh provinsi yang ada di Indonesia, Bangka Belitung (Babel) adalah salah satu provinsi dengan tingkat pernikahan anak yang tinggi, yakni menempati posisi tertinggi ketiga. Menurut Deputi Menteri Pemberdayaan Perempuan dan Perlindungan Anak (PPA) 
bidang tumbuh kembang anak, Lenny N Rosalin, secara nasional angka pernikahan di bawah umur (pernikahan anak) mencapai angka 25\%, sementara itu untuk Babel sudah mencapai $37 \%$ (Sakti, 2019).

Secara sosiologis, fenomena pernikahan anak dengan persentase yang tinggi sebagaimana yang sudah terjadi di Babel ini, harus menjadi salah satu prioritas kajian ilmiah, guna melihat bagaimana dinamika sosial terkait fenomena ini secara lebih jauh, lalu pada akhirnya bisa memberikan narasi konstruktif yang bisa dipertanggungjawabkan secara akademik, juga kepada publik. Adapun yang menjadi fokus kajian, yaitu mengenai penyebab dan bagaimana dampak (baik secara kesehatan, ekonomi, sosial, budaya, maupun politik) dari terjadinya fenomena pernikahan anak di Bangka Belitung.

Dalam agama sendiri tentu sangat melarang adanya perceraian. Bahkan sepanjang sejarah kehidupan umat manusia, konteks perceraian justru tidak dapat dihentikan begitu saja, dan terus berlangsung dari waktu ke waktu, akibatnya ada begitu banyak konsekuensi traumatis, sakit hati, kecewa, depresi berat, dan mungkin mengalami gangguan jiwa akibat perceraian tersebut (Widayanti, Lestari \& Hidayah, 2014).

Atas dasar permasalahan diatas maka studi ini mencoba mengungkapkan berbagai faktor determinan pendorong terjadinya pernikahan dini dan perceraian. Kemudian, studi ini juga berupaya menjelaskan berbagai aspek sosiologis, khususnya dampak sosial dari kompleksitas demografi pernikahan dan perceraian yang terjadi. Studi ini pada gilirannya hendak mentelaah secara kritis terkait beberapa hal, yaitu pertama; bagaimana dinamika dan realitas pernikahan dini dan perceraian di Bangka Belitung, Kedua; apasaja faktor-faktor penyebab pernikahan dini dan perceraian terjadi, Ketiga; bagaimana dampak sosial atas fenomena tersebut terhadap demograsi sosial masyarakat lokal.

\section{METODE PENELITIAN}

Tulisan ini diperoleh dari kajian penelitian dengan menggunakan pendekatan model kualitatif deskriptif (Moleong, 2004), yang menggambarkan bagaimana realitas dan kompleksitas tren nikah dini dan perceraian saling bertalian satu sama lain. Teknik pengumpulan data menggunakan metode kajian literature review, dan metode literature review, serta rangkaian analisis dokumen yang relevan dengan konteks kajian. Lokus kajian penelitian ini yaitu di lingkungan Provinsi Kepulauan Bangka Belitung. Untuk memperkaya analisis data, peneliti juga melakukan observasi dan wawancara ke lapangan dalam rangka mencermati realitas data dokumen dengan kondisi ril di masyarakat.

\section{HASIL PENELITIAN DAN PEMBAHASAN Pernikahan Dini dan Tingkat Perceraian}

Jika mengacu pada data BKKBN, 2012, menjelaskan bahwa provinsi dengan presentasi perkawinan dini usia 15-19 tahun di Bangka Belitung tercatat mencapai 47,9\%. Hal tersebut terlihat bahwa Kepulauan Bangka Belitung merupakan salah satu provinsi dengan tingkat persentasi perwakinan dini (antara usia 15-19 tahun) tertinggi di Indonesia. Kondisi ini tentu menjadi keprihatinan semua pihak dalam menyoal persoalan demografi pernikahan dini yang terus mengalami tren peningkatan setiap tahunnya (BKKBN, 2012).

Tren peningkatan ini kemudian menjadi atensi serius banyak pihak dalam beberapa tahun belakangan, terlebih dengan data empiris lain yang juga menunjukkan bahwa tingkat penderita Stunting di Bangka Belitung juga relatif sangat tinggi, misalnya Balita penderita stunting mencapai 23,37\%. Pada tahun 203-204 misalnya, Kabupaten Bangka dan Kabupaten Bangka Barat merupakan dua wilayah dengan tingkat stunting cukup tinggi, bahkan masuk kategorisasi kasus gizi kronis (Pratama, 2019; Saputri, 2019). Konteks ini tentu sedikit banyak juga bertalian kuat dengan realitas dan kualitas relasi kekeluargaan yang dipicu oleh tren pernikahan dini yang tinggi dalam beberapa tahun terakhir. 
Kajian yang digunakan untuk menelaah pernikahan dini dan tingkat perceraian di Bangka Belitung mengacu pada sosio-kultural masyarakat Bangka Belitung UU Nomor 16 Tahun 2019 tentang Perubahan Atas UU Nomor 1 Tahun 1974 tentang Perkawinan. Jika dalam UU Nomor 1 Tahun 1974 tentang perwakinan mengatakan bahwa pernikahan boleh dilakukan di Indonesia apabila perempuan berusia paling kurang 16 tahun dan lelaki 19 tahun, sementara itu di UU nomor 16 Tahun 2019 ketentuan tersebut diubah, bahwa dalam batasan usia perkawinan antara pria dan perempuan tidak ada perbedaan. Batas minimal usia pasangan mempelai antara pria dan wanita adalah 19 tahun. Konteks inilah kemudian yang menjadi basis pijakan dalam mendefinisikan konsep pernikahan dalam kajian demografi ini.

Mengacu dari pengertian di atas dapat dipahami bahwa diluar batas usia 19 tahun yang sudah diatur termasuk sebagai pernikahan dini. Dengan demikian, maka pernikahan dini merupakan konteks pernikahan yang berlangsung pada saat di bawah usia yang seharusnya belum siap untuk melaksanakan pernikahan.

Telah diuraikan sebelumnya bahwa, secara nasional angka pernikahan di bawah umur mencapai 25 persen, sedangkan untuk wilayah Provinsi Kepulauan Bangka Belitung mencapai 37 persen. Tingginya angka dalam perkawinan usia dini sangat rentan terjadinya perceraian (BKKBN Provinsi Kep.Babel dan PSKK UBB, 2017). Pemerintah Provinsi Kepulauan Bangka Belitung mengatakan kasus perceraian pada pasangan suami istri muda tinggi. Hal itu karena mereka belum bisa mempersiapkan kehidupan rumah tangga dengan baik. Di sisi lain ditemukan bahwa kasus perceraian di Pengadilan Agama mengalami peningkatan.

Dalam beberapa catatan di media massa, terlihat tingginya kasus gugat cerai dari pasangan suami istri muda di Pengadilan Agama Bangka Belitung mengalami peningkatan, sehingga memicu angka perceraian. Kasus perceraian ini rata-rata berasal dari pasangan suami isteri yang menikah dalam usia dini.

Setidaknya, tercatat dari tiga tahun terakhir, khususnya pada tahun 2017 terdapat cerai talak yang dikabulkan oleh pengadilan agama sebanyak 211 kasus, serta kasus cerai gugat sebanyak 513. Kemudian, pada medio 2018, terdapat cerai talak sebanyak 221 kasus, dan cerai gugat sebanyak 552 kasus. Kemudian, pada medio 2019, untuk Bulan Oktober 2019 tercatat ada 216 kasus perceraian, dan kasus gugat cerai sebanyak 634. Angka tersebut kemudian terus mengalami tren peningkatan setiap bulannya (Pratama, 2019).

\section{Lanskap Ekonomi Ekstraktif \& Konsekuensi Sosial}

Kepulauan Bangka Belitung merupakan salah satu daerah dengan potensi sumber daya yang cukup variatif dan berlimpah (Heidhues, 2008; Ibrahim, Zukhri \& Rendy, 2019). Selama dari dua dasawarsa terakhir, tumpuan ekonomi lokal justru cukup besar ketergantungannya pada sektor pertambangan timah, baik di darat maupun di laut. Hingga saat ini, limpahan sumber daya timah masih juga mewarnai perekonomian lokal di Bangka Belitung.

Konteks pengelolaan sumber daya pertambangan selama ini dilakukan secara eploitatif dan destruktif sehingga menimbulkan berbagai konsekuensi sosial serius dalam masyarakat. Akibat salah satunya yaitu adanya perubahan sosial dalam model relasi sosial dan ekonomi masyarakat yang terkesan semakin pragmatis, serba instan dan semakin konsumtif.

Beberapa hasil kajian riset menunjukkan bagaimana besarnya pengaruh aktivitas pertambangan timah dalam beberapa tahun terakhir sudah banyak merubah struktur sosial di masyarakat lokal, seperti pola ekonomi yang konfliktual, kerusakan lingkungan yang cukup masif, tingkat putus sekolah dan pola prilaku penyimpangan yang kerap terjadi. Konteks ini sejalan dengan fenomena tambang yang dinilai Erwiza selalu identik dengan tiga persoalan utama: judi, prostitusi, dan kriminalitas. Ketiga konteks tersebut tidak jarang saling berkelindan satu sama lain sehingga menyebabkan kondisi paradoks dalam lingkungan sosial masyarakat selama ini (Erman, 2010; Mastira, Zukhri \& Saputra, 2020) 
Lebih lanjut, praktik ekploitasi pertimahan di Bangka Belitung telah banyak mempengaruhi perubahan pola topografi dan juga lanskap sosial ekonomi yang berlangsung secara serius dan masif dalam beberapa tahun terakhir. Beberapa konteks yang dimaksud misalnya praktik prostitusi yang semakin bermunculan, perjudian liar, pola hidup yang semakin hedonis, konsumtif, dan terjadi eksploitasi terhadap anak-anak dalam aktivitas produksi pertambangan timah, dan juga tingkat pernikahan dini, perceraian dan munculnya berbagai penyakit berbahaya akibat bermunculannya kubangan air dalam skala besar bekas pertambangan timah (Rendy, Wulansari \& Zarina, 2019).

\section{Faktor-Faktor Penyebab Pernikahan Dini Dan Keputusan Bercerai Pasangan Usia Muda}

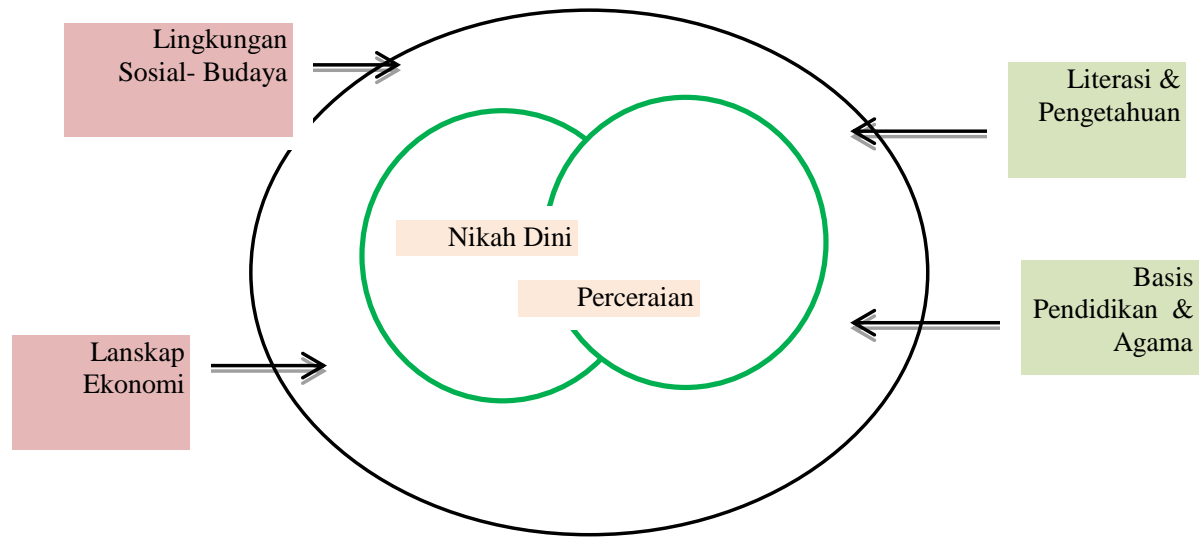

Tingginya angka pernikahan di bawah umur di Provinsi Kepulauan Bangka Belitung, banyak diantara pasangan usia muda menyandang status sebagai duda dan janda. Ironisnya, status tersebut justru dihadapi oleh mereka yang masih berusia muda, dan tidak sedikit yang masih usia sekolah. Beberapa hal yang mendorong terjadinya pernikahan dini, dan pada gilirannya harus menghadapi problem perceraian, diantaranya disebabkan oleh beberapa persoalan berikut ini:

Pertama, pola pendidikan keluarga yang kurang memadai. Hal ini juga dipengaruhi oleh lanskap sosial-ekonomi keluarga pekebun dan penambang yang menyebabkan kecilnya perhatian orangtua terhadap anak.

Kedua, rendahnya literasi dan pengetahuan pemuda-pemudi tentang pernikahan, baik dari aspek keagamaan, sosial, dan ekonomi. Akibatnya, hal tersebut mempengaruhi kapasitas pasangan usia muda untuk menjalin hubungan pernikahan secara harmonis. Selain itu, keputusan menikah di usia muda juga kerapkali tanpa diikuti oleh pertimbangan yang matang dan mendalam. Hal ini juga diperparah oleh pola bimbingan dan dukungan orangtua yang kerapkali menyederhanakan agar si anak bisa lebih mandiri, dan sekaligus juga bisa memberika anak-anak mereka agar bisa bertanggungjawab terhadap persoalannya sendiri.

Ketiga, latar belakang pendidikan formal yang kebanyakan belum memadai juga menyebabkan lemah dan rendahnya semangat untuk menunda usia pernikahan. Hal ini pada gilirannya juga menyebabkan para anak muda usia sekolah memutuskan untuk segera menikah dan bisa mendapatkan penghasilan sendiri. Dari sisi kematangan dan kedewesaan berpikir, tentu kondisi ini menimbulkan kompleksitas tersendiri dalam hubungan pernikahan usia muda. Kondisi ini juga menyebabkan mudahnya keputusan untuk bercerai ketika pasangan usia muda menghadapi persoalan dalam kehidupan rumah tangga mereka.

Keempat, rendahnya pengetahuan agama juga menyebabkan mudahnya pasangan usia muda untuk melakukan pelanggaran hubungan dalam bahtera rumah tangga. Adanya pihak ketiga dalam hubungan berumah tangga juga menjadi penyebab rentannya hubungan pasangan usia muda dalam menjalankan hubungan mereka. Kondisi ini juga menyebabkan 
rendahnya sakralitas pernikahan bagi pasangan usia muda yang memutuskan untuk menikah muda.

Untuk menyederhanakan alur persoalan yang menjadi kompleksitas demografi pernikahan dini dan perceraian di Bangka Belitung, dapat dilihat dari struktur bagan berikut ini:

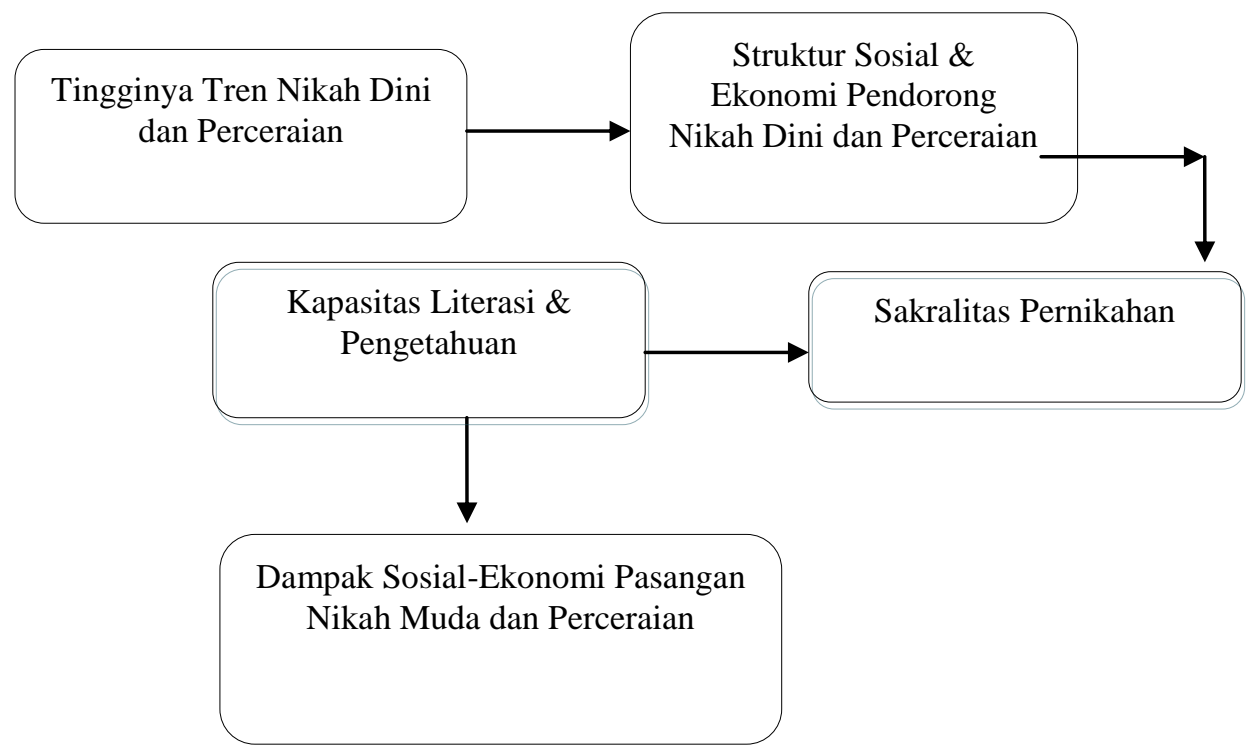

Selain itu, terdapat juga beberapa faktor yang memaksa mereka kemudian untuk harus menikah dalam usia dini atau sebaliknya bubar pasangan sebagai suami isteri karena harus cerai (Karim, 1999). Terdapat dua faktor penyebab terjadinya pernikahan dini pada kalangan remaja, yaitu sebab dari dan dari luar anak. Beberapa faktor yang dimaksud diantaranya:

a. Sebab dari anak

1. Faktor Pendidikan

Pendidikan anak-anak memiliki peran strategis dalam menentukan jalan hidup mereka ke depannya. Konteks ini sangat mempengaruhi kualitas demografi lokal, termasuk dalam hal menikah dini atau tidak. Fakta selama ini kerapkali ditemukan jika seorang anak lebih fokus sekolah dan/ atau mempunyai impian sekolah sampai perguruan tinggi, maka anak tersebut menjadi tidak terpikirkan untuk menikah selama masih dalam proses sekolah (meskipun sanga anak ketika SMA misalnya sudah mulai pacaran). Namun apabila seorang anak mengalami putus sekolah pada usia wajib sekolah, kemudian mengisi waktu dengan bekerja, biasanya sang anak merasa dirinya cukup mandiri, sehingga merasa mampu menghidupi diri sendiri (dan bahkan orang lain). Dalam keadaan seperti itu, maka tidak menutup kemungkinan, bagi sang anak apabila ia memutuskan untuk menikah (meski dalam usia yang masih dini), maka dianggapnya hal tersebut tidaklah menjadi persoalan.

Demikian halnya juga ketika anak yang putus sekolah tersebut menganggur. Dalam kekosongan waktu tanpa pekerjaan membuat mereka seringkali akhirnya melakukan hal-hal yang tidak produktif. Salah satunya bisa saja menjalin hubungan dengan lawan jenis, yang jika tidak bisa terkontrol baik oleh dirinya sendiri ataupun keluarga, maka bisa saja membuat sang anak terjerumus untuk melakukan hubungan intim, sehingga terjadilah kehamilan di luar nikah.

2. Faktor telah melakukan hubungan biologis.

Pernah terjadi beberapa kasus pernikahan dini di Bangka Belitung yang menunjukkan pasangan yang masih dalam usia anak 'terpaksa' dinikahkan keluarganya karena dinilai mereka sudah terlanjur melakukan hubungan biologis ataupun hubungan intim. Hal yang kerap terjadi, dalam kasus seperti itu, orang tua anak perempuan yang lebih cenderung ingin segera menikahkan anaknya, karena menurut mereka ketika sang anak 
perempuan tidak perawan lagi akan menjadi aib yang sangat memalukan bagi keluarga di tengah masyarakat. Tanpa mengenyampingkan perasaan dan kegalauan orang tua, hal ini sebuah solusi yang kemungkinan di kemudian hari akan menyesatkan anak-anak. Ibarat anak sudah melakukan suatu kesalahan yang besar, bukan memperbaiki kesalahan tersebut, tetapi orang tua justru membawa anak pada suatu kondisi yang rentan terhadap masalah. Karena sangat besar di kemudian hari perkawinan anak-anak tersebut akan dipenuhi konflik.

3. Sang anak mengalami kehamilan

Ketika terjadi kehamilan di luar nikah terhadap sang anak, seolah hanya menikah menjadi jalan penyelesaian tersebut. Di Bangka Belitung terjadi realitas demikian, terlepas dari kondisi sang anak yang sebetulnya secara usia dan kondisi finansial tidak memungkinkan untuk dinikahkan. Bahkan ada beberapa kasus walau ada dasarnya bagi orang tua anak perempuan tidak setuju dengan calon menantunya, tapi karena kondisi kehamilan sang anak, maka orang tua tersebut lebih memilih untuk memaksakan anak perempuannya menikah sang lelaki yang sebetulnya tidak setuju. Bahkan ada kasus, justru anak gadis tersebut pada dasarnya tidak mencintai calon suaminya, tapi karena terlanjur hamil, maka dengan sangat terpaksa mengajukan permohonan dispensasi kawin. Kondisi ini semua tentu sangat dilematis, baik bagi anak gadis, orang tua bahkan hakim yang menyidangkan. Terlebih konteks perkawinan yang dilakukan bukan lagi perkawinan yang sejalan dengan prinsp dan prasarat UU bahkan agama (Gunawan, 2000).

b. Sebab dari Luar Anak

1. Faktor Pemahaman Agama.

Ada sebagian dari masyarakat kita yang memahami bahwa jika anak menjalin hubungan dengan lawan jenis, telah terjadi pelanggaran agama. Dan sebagai orang tua wajib melindungi dan mencegahnya dengan segera menikahkan anak-anak tersebut. Ada satu kasus, dimana orang tua anak menyatakan bahwa jika anak menjalin hubungan dengan lawan jenis merupakan satu: "perzinahan". Oleh karena itu sebagai orang tua harus mencegah hal tersebut dengan segera menikahkan. Saat mejelis hakim menanyakan anak wanita yang belum berusia 16 tahun tersebut, anak tersebut pada dasarnya tidak keberatan jika menunggu dampai usia 16 tahun yang tinggal beberapa bulan lagi. Tapi orang tua yang tetap bersikukuh bahwa pernikahan harus segera dilaksanaka. Bahwa perbuatan anak yang saling suka sama suka dengan anak laki-laki adalah merupakan "zina". Dan sebagai orang tua sangat takut dengan azab membiarkan anak tetap berzina. (Undang-Undang No. 1 Tahun 1974 Tentang Perkawinan, 2007).

2. Faktor Ekonomi

Kita masih banyak menemui kasus-kasus dimana orang tua terlilit hutang yang sudah tidak mampu dibayarkan. Dan jika si orang tua yang terlilit hutang tadi mempunyai anak gadis, maka anak gadis tersebut akan diserahkan sebagai "alat pembayaran" kepada si piutang. Dan setelah anak tersebut dikawini, maka lunaslah hutang-hutang yang melilit orang tua si anak.

3. Faktor Adat dan Budaya

Di beberapa belahan daerah di Indonesia, masih terdapat beberapa pemahaman tentang perjodohan. Dimana anak gadisnya sejak kecil telah dijodohkan orang tuanya. Dan akan segera dinikahkan sesaat setelah anak tersebut mengalami masa menstruasi. Padahal umumnya anak-anak perempuan mulai menstruasi di usia 12 tahun. Maka dapat dipastikan anak tersebut akan dinikahkan pada usia 12 tahun, jauh di bawah batas usia minimum sebuah pernikahan yang diamanatkan UU.

\section{Dampak Pernikahan Dini}

Resiko pernikahan dini berkait erat dengan beberapa aspek sebagai berikut:

1. Segi Kesehatan

DOI: https://doi.org/10.33019/jpi.v2i1.18 
Dilihat dari segi kesehatan, pasangan usia muda dapat berpengaruh pada tingginya angka kematian ibu yang melahirkan, kematian bayi serta berpengaruh pada rendahnya derajat kesehatan ibu dan anak. Menurut ilmu kesehatan, bahwa usia yang kecil resikonya dalam melahirkan adalah antara usia 20-35 tahun, artinya melahirkan pada usia kurang dari 20 tahun dan lebih dari 35 tahun mengandung resiko tinggi. Ibu hamil usia 20 tahun ke bawah sering mengalami prematuritas (lahir sebelum waktunya) besar kemungkinan cacat bawaan, fisik maupun mental, kebutaan dan ketulian.

2. Segi Fisik

Pasangan usia muda belum mampu dibebani suatu pekerjaan yang memerlukan keterampilan fisik, untuk mendatangkan penghasilan baginya, dan mencukupi kebutuhan keluarganya. Faktor ekonomi adalah salah satu faktor yang berperan dalam mewujudkan dalam kesejahteraan dan kebahagiaan rumah tangga. Generasi muda tidak boleh berspekulasi apa kata nanti, utamanya bagi pria, rasa ketergantungan kepada orang tua harus dihindari.

Tren fenomena pernikahan dini disertai persoalan talak cerai maupun gugat cerai dalam hubungan perkawinan usia muda merupakan paradoks tersendiri yang menjelaskan kondisi ketidakmatangan sekaligus ketidakharmonisan dalam proses menjalankan bahtera kehidupan dalam rumah tangga. Oleh karena itu, berbagai potret kerumitan masalah yang dihadapi pasangan nikah dini maupun pasangan bercerai, tidak terlepas dari dinamika persoalan dalam rumah tangga itu sendiri, yang kerapkali mengalami banyak kerentanan sosial dan ekonomi, misalnya kemampuan untuk memperoleh pekerjaan secara memadai, sekaligus juga pada waktu bersamaan, muncul beragam persoalan di rumah tangga, yang pada dasarnya memerlukan atensi yang tidak hanya terbatas dari pemerintah semata.

\section{Dimensi Sosiologis dan Politis Tren Nikah Dini dan Cerai}

Jika berbicara isu perkawinan, tentu merupakan sesuatu yang dianggap sakral dalam kehidupan masyarakat, sehingga perkawinan erat kaitannya dengan persoalan agama. Oleh karena itulah mengapa kemudian diskursus nikah dini dan perceraian menjadi dua aspek yang saling bertalian kuat satu sama lain, sebagaimana hal tersebut juga menggejala di lingkungan Provinsi Kepulauan Bangka Belitung. Ada begitu banyak aspek sosiologis dan politis yang menyebabkan tren tersebut terus berkembang dalam satu dasawarsa terakhir. Beberapa aspek sosiologi dan politis yang dimaksud diantaranya:

Pertama, geliat ruang perekonomian lokal yang memiliki ketergantungan yang relatif besar terhadap sektor ekstraktif dalam 15 tahun terakhis, justru telah memicu perubahan sosial perilaku masyarakat lokal, yang cenderung konsumtif, dan hedonis. Potret perekonomian lokal tersebut justru tidak bisa dilepaskan dari konteks pilihan kebijakan yang diambil oleh pemerintah daerah, yang menimbang penting tentang akses masyarakat lokal terhadap sumber daya timah.

Ketiga, masih lemah atau terbatasnya intervensi dan program pemerintah daerah yang lebih interaktif dan sosialitatif terhadap berbagai kebutuhan dan situasi yang sesuai dengan kondisi di lapangan. Konteks ini yang kerapkali diabaikan. Akibatnya, tentu muncul gejolak di lingkungan masyarakat yang rentan terhadap berbagai persoalan sosial maupun ekonomi di lingkungan rumah tangga.

Keempat, tingkat pengetahuan para pasangan nikah dini, termasuk juga yang memutus untuk bercerai relatif masih cukup terbatas untuk memahami berbagai kerumitan persoalan yang dihadapi oleh pasangan nikah muda, dan keputusan cepat untuk bercerai

\section{Perceraian}

Perceraian adalah cerai hidup antara pasangn suami isteri sebagai akibat dari kegagalan mereka menjalankan obligasi peran masing-masing. Dalam hal ini perceraian dilihat sebagai akibat dan suatu ketidakstabilan erkawinan dimana pasangan suami isteri kemudian hidup terpisah dan secara resmi diakui oleh hukum yang berlaku (Karim, 1999; Abdullah, 2013; 
Dagun, 2002). Perceraian merupakan terputusnya keluarga karena salah satu atau kedua pasangan memutuskan untuk saling meninggalkan sehingga mereka berhenti melakukan kewajibannya sebagai suami istri.

Dalam sosiologi, terdapat teori pertukaran yang melihat perkawinan sebagai suatu proses pertukaran antara hak dan kewajiban serta penghargaan dan kehilangan yang terjadi diantara sepasang suami istri. Oleh karena itu, perkawinan merupakan proses integrasi dua individu yang hidup dan tinggal bersama, sementara latar belakang sosial-budaya, keinginan serta kebutuhan mereka berbeda, maka proses pertukaran dalam perkawinan ini harus senantiasa dirundingkan dan disepakati bersama. Beberapa faktor penyebab perceraian antara lain adalah sebagai berikut:

1. Ketidak harmonisan dalam Rumah Tangga

Alasan tersebut di atas adalah alasan yang paling kerap dikemukakan oleh pasangan suami - istri yang akan bercerai. Ketidakharmonisan bisa disebabkan oleh berbagai hal antara lain, krisis keuangan, krisis akhlak, dan adanya orang ketiga. Dengan kata lain, istilah keharmonisan adalah terlalu umum sehingga memerlukan perincian yang lebih mendetail.

2. Krisis Moral dan Akhlak

Selain ketidakharmonisan dalam rumah tangga, perceraian juga sering memperoleh landasan berupa krisis moral dan akhlak, yang dapat dilalaikannya tanggung jawab baik oleh suami ataupun istri, poligami yang tidak sehat, penganiayaan, pelecehan dan keburukan perilaku lainnya yang dilakukan baik oleh suami ataupun istri, misal mabuk, berzina, terlibat tindak kriminal, bahkan utang piutang.

3. Perzinahan.

Di samping itu, masalah lain yang dapat mengakibatkan terjadinya perceraian adalah perzinaan, yaitu hubungan seksual di luar nikah yang dilakukan baik oleh suami maupun istri. 1. Pernikahan tanpa Cinta.

Alasan lainnya yang kerap dikemukakan oleh suami dan istri, untuk mengakhiri sebuah perkawinan adalah bahwa perkawinan mereka telah berlangsung tanpa dilandasi adanya cinta. Untuk mengatasi kesulitan akibat sebuah pernikahan tanpa cinta, pasangan harus merefleksi diri untuk memahami masalah sebenarnya, juga harus berupaya untuk mencoba menciptakan kerjasama dalam menghasilkan keputusan yang terbaik.

4. Adanya Masalah-masalah dalam Perkawinan

Dalam sebuah perkawinan pasti tidak akan lepas dari yang namanya masalah. Masalah dalam perkawinan itu merupakan suatu hal yang biasa, tapi percekcokan yang berlarut-larut dan tidak dapat didamaikan lagi secara otomatis akan disusul dengan pisah ranjang seperti adanya perselingkuhan antara suami istri.

\section{SIMPULAN}

Berdasarkan hasil studi ini, dapat disimpulkan bahwa dampak sosial nikah dini dan perceraian di Kepulauan Bangka Belitung pada akhirnya mempengaruhi berbagai aspek sosial dan kualitas relasi sosial-ekonomi masyarakt. Konteks tersebut tidak bisa dilepaskan begitu saja dari konteks kerentanan yang kerapkali dihadapi para pasangan menikah. Tren nikah muda dan cerai tersebut juga dipicu oleh lanskap sosial dan perekonomian lokal yang sejak beberapa tahun terakhir tetap bergantung pada sektor ekstraktif pertambangan. Sementara itu, berdasarkan telaah dokumen secara mendalam, dapat disimpulkan bahwa secara umum isu dan dampak nikah dini dan perceraian memiliki hubungan yang cukup erat. Dalam hal ini, mudah sekali bagi mereka pasangan nikah dini menghadapi berbagai persoalan penting dalam lingkup keluarga. Tren nikah muda dan pasangan cerai di lingkungan Provinsi Kepulauan Bangka Belitung memperlihatkan bahwa angka perkawinan usia dini mencapai 37 persen, dan 3 tertinggi dalam wilayah provinsi di Indonesia. Kondisi tersebut tentu menjadi kompleksitas tersendiri dalam realitas demografi kekeluargaan di Bangka Belitung. Studi ini juga menunjukkan bagaimana masih lemah dan terbatasnya intervensi pemerintah daerah 
dalam hal memberikan semacam program asistensi atau intervensi solutif, baik dari aspek kebijakan maupun dalam dimensi program yang berkorelasi langsung terhadap penguatan kualitas kesiapan dan kematangan bagi pasangan usia muda dalam dalam membina bahtera rumah tangga. Oleh karena itu, kedepannya, perlu sebuah desain kebijakan yang tidak berdimensi ekonomi semata, akan tetapi perlu penguatan aspek sosiologis-politis yang melibat semua stakeholders, yang tidak hanya pemerintah, akan tetapi ada swasta atau dunia usaha, dan masyarakat dalam mengentaskan persoalan tren pernikahan dini dan perceraian yang terus mengalami tren peningkatan dalam beberapa tahun terakhir.

\section{DAFTAR PUSTAKA}

Abdullah, B., \& Saebani, B. A. (2013). Perkawinan dan Perceraian Keluarga Muslim. Bandung: CV pustaka setia.

BKKBN Provinsi Kepulauan Bangka Belitungdan PSKK UBB. (2017). Antara Idealistis dan Realistis: Analisis Faktor Ekonomi dan Alternatif Penekanan Angka Perceraian di Belitung. BKKBN

Badan Kependudukan dan Keluarga Berencana Nasional.(2012. Pernikahan Dini Pada Beberapa Provinsi di Indonesia Dampak Over Population, Akar Masalah, dan Peran Kelembagaan di Daerah. (Pokja Dampak Sosial-Ekonom terhadap Kependudukan Ditdamduk $B K K B N$ 2012). https://www.academia.edu/16972864/hasil_pernikahan_usia_dini_BKKBNPPT_RS_Read-Only

Dagun, S. M. (2002). Psikologi keluarga. Jakarta: Rineka Cipta.

Erman, E. (2017). Aktor, akses dan politik lingkungan di pertambangan timah Bangka. Masyarakat Indonesia, 36(2), 71-101. https://doi.org/10.14203/jmi.v36i2.640

Gunawan, F. R. (2000). Mendobrak tabu: sex kebudayaan dan kebejatan manusia. Galang Press.

Heidhues, M. F. S. (2008). Bangka Tin and Mentok Pepper, Chinese People Role in 18th to 20th Century Bangka Island Development. Jakarta: Yayasan Nabil.

Hidayat, R. (2019, September 17). DPR Kukuhkan Batas Usia Perkawinan Minimum 19 Tahun.

Hukumonline.Com. https://www.hukumonline.com/berita/baca/lt5d7fcb7fc88bd/dpr-kukuhkan-batas-usiaperkawinan-minimum-19-tahun/

Ibrahim, I., Zukhri, N., \& Rendy, R. (2019). Between Tourism and Ecology: Review of Political Policy Commitments on Ecotourism Development in Bangka Belitung. In E3S Web of Conferences (Vol. 118, p. 04008). EDP Sciences. Doi: https://doi.org/10.1051/e3sconf/201911803016

Idrus, I. A., \& Ferdian, K. J. (2019). Implementasi Pelayanan Publik Pada Program SIDUKUN 3 In 1 Dalam Pengurusan Administrasi Kependudukan Di DKI Jakarta. Journal of Governance and Local Politics, 1(2), 193-204. Doi: http://journal.unpacti.ac.id/index.php/JGLP/article/view/28

Karim, E. (1999). Pendekatan perceraian dari perspektif sosiologi. Dalam Ihromi, Bunga Rampai Sosiologi Keluarga. Jakarta: Yayasan Obor Indonesia.

Kementerian Pemberdayaan Perempuan dan Perlindungan Anak Republik Indonesia. (2016). Perkawinan Anak dalam Perspektif Islam, Katolik, Protestan, Budha, Hindu dan Hindu Kharingan (Studi Kasus di Kota Palangkaraya dan Kabupaten Katingan, 
Provinsi Kalimantan Tengah). https://www.kemenpppa.go.id/lib/uploads/list/b1daclaporan-penelitian-perkawinan-anak.pdf

Mastira, O., Zukhri, N., \& Saputra, D. (2020). Comparative Analysis of Growth Rate and Contribution of Local Taxes to Local Own Revenues in the City of Pangkalpinang and Belitung Regency. Journal of Political Issues, 1(2), 115-124. Doi: https://doi.org/10.33019/jpi.v1i2.12

Moleong, L. J. (2004). Metodologi Penelitian Kualitatif. Bandung: PT Remaja Rosdakarya.

Nusantara, S. S. (2020). Angka Perkawinan Anak Indonesia, Tertinggi Kedua di ASEAN | Milenial. Gatra.Com. https://www.gatra.com/detail/news/428942/milenial/angkaperkawinan-anak-indonesia-tertinggi-kedua-di-asean\#

Pratama, R. (2019, November 22). Angka Perceraian Tinggi di Bangka, Kepala Kemenag Bangka Ungkap Penyebabnya. Bangka Pos.

https://bangka.tribunnews.com/2019/11/22/angka-perceraian-tinggi-di-bangka-kepalakemenag-bangka-ungkap-penyebabnya

Rahmawati, Dewi. Pernikahan Anak di Indonesia peringkat dua ASEAN. 2020. https://lokadata.id/artikel/pernikahan-anak-di-indonesia-peringkat-dua-asean. Diakses 10 April 2020

Rendy, R., Wulansari, D., \& Zarina, B. (2019). Demografi Politik Kewargaan Daerah Pinggiran Kota Pangkalpinang. Journal of Political Issues, 1(1), 35-49. Doi: https://doi.org/10.33019/jpi.v1i1.5

Sakti, A. T. (2019, March 1). Angka Pernikahan Dini di Babel Memprihatinkan, Nomor Tiga Tertinggi di Indonesia. Bangka Pos. https://bangka.tribunnews.com/2019/03/01/angkapernikahan-dini-di-babel-memprihatinkan-nomor-tiga-tertinggi-di-indonesia

Saputri, R., \& Tumangger, J. (2019). Hulu-hilir Penanggulangan Stunting Di Indonesia. Journal of Political Issues, 1(1), 1-9. Doi: https://doi.org/10.33019/jpi.v1i1.2

Undang-undang No. 1 Tahun 1974 Tentang Perkawaninan. (2007). www.pasunguminasa.go.id. Sumber: https://www.pasungguminasa.go.id/pdf/UU\%20nomor\%201\%201974.pdf

Widayanti, A., Lestari, P., \& Hidayah, N. (2014). Faktor-faktor penyebab perceraian pada keluarga tenaga kerja wanita (TKW) di desa Citembong, Kecamatan Bantarsari, Kabupaten Cilacap [Causes of divorce in the family of women migran workers in Citembong Village, Bantarsari District, Cilacap Regency]. Universitas Negeri Yogyakarta. 